\title{
Effect of calcium salt of long-chain fatty acids and alfalfa supplementation on performance of Holstein bulls
}

\author{
Yang He ${ }^{1}$, Wenjing Niu${ }^{1}$, Qinghua Qiu ${ }^{1}$, Chuanqi Xia ${ }^{1}$, Taoqi Shao ${ }^{1}$, Haibo Wang ${ }^{1}$, \\ Qianwen Li ${ }^{1}$, Zhantao Yu ${ }^{1}$, Zhibiao Gao ${ }^{1}$, Muhammad Aziz Ur Rahman ${ }^{2}$, Huawei Su${ }^{1}$ \\ and Binghai Cao ${ }^{1}$ \\ ${ }^{1}$ State Key Laboratory of Animal Nutrition, College of Animal Science and Technology, China Agricultural University, Beijing, \\ China \\ ${ }^{2}$ Gomal College of Veterinary Sciences, Gomal University, D.I. Khan, KPK, Pakistan \\ Correspondence to: Binghai Cao, email: caobhchina@163.com \\ Huawei Su, email: suhuawei@cau.edu.cn \\ Keywords: calcium salt of long-chain fatty acids; alfalfa; rumen microbial flora; serum biochemical indexes; Holstein bulls \\ Received: August 24, $2017 \quad$ Accepted: November 14, $2017 \quad$ Published: December 09,2017 \\ Copyright: He et al. This is an open-access article distributed under the terms of the Creative Commons Attribution License 3.0 (CC \\ BY 3.0), which permits unrestricted use, distribution, and reproduction in any medium, provided the original author and source are \\ credited.
}

\section{ABSTRACT}

The purpose of this study was to assess the effects of calcium salt of longchain fatty acids (CSFA) and alfalfa on beef cattle in the late fattening. 48 Holstein bulls were selected and randomly divided into 4 groups, feeding four dietary that Leymus chinensis with (LC) or with no (LN) $2.4 \%$ CSFA, and alfalfa replaced $50 \%$ Leymus chinensis with (AC) or with no (AN) $2.4 \%$ CSFA. The results indicated that alfalfa improved the feed conversion rate $(P<0.05)$. CSFA increased serum low density lipoprotein cholesterol, and reduced the cooking loss of Longissimus muscle $(P<0.05)$. CSFA and alfalfa reduced Acetate/Propionate. Alfalfa and CASF had significant additive effects on the apparent digestibility of dry matter, crude protein, neutral detergent fiber, acid detergent fiber, organic matter and rumen fermentation for acetate, isobutyrate, butyrate, isovalerate, total volatile fatty acids $(P<0.05)$. CSFA increased microbial diversity index when compared with alfalfa $(P<0.05)$, but no significant differences were detected in bacterial genera abundances among diets. The relative abundances of rumen bacterial genera have significant correlation with apparent digestibility of nutrients, rumen fermentation characteristics and serum biochemical parameters $(P<0.05)$. These results comprehensively evaluated the additive effects of alfalfa and CSFA on the application in Holstein bulls.

\section{INTRODUCTION}

Holstein bulls had been often used to product meat as beef cattle in China. In order to improve the yield and quality of meat, ration often contains relatively high concentrates for beef cattle to deposit fat during the process of finishing. However, feed diets with high readily fermentable carbohydrates usually lead to subclinical acidosis of rumen and adverse to the long-time growth performance of beef cattle. Thus, by providing highquality forage or adding oils to improve feed energy values could alleviate the rumen acidosis. On account of plant oils especially unsaturated fats are harmful to rumen micro-organisms [1], and bio-hydrogenation in rumen would transfer unsaturated fatty acids into saturated fatty acids [2]. Therefore, it is very necessary to use rumenprotected fat in the production.

CASF have been widely used in dairy as one of rumen-protected fats. It has been confirmed that the CASF can ameliorate energy negative balance for transition dairy heifers [3], increase the fat and dressing percentage of the beef [4]. Moreover, CASF can increase fiber digestibility and decrease rumen microbial bio-hydrogenation [5], thereby increasing the content of unsaturated fatty acids in milk and meat products, which are metabolically beneficial to human health. Ruminant liver metabolism is affected 
by the content and type of fatty acids in diet, ultimately change the composition of lipids in the blood [6].

As we know, the beef cattle growth performance and meat quality are influenced by diet factors. For example, alfalfa as a high quality roughage, provides protein in ruminant nutrition, can reduce the oxidation of fat and increasing the proportion of unsaturated fatty acids in the fat and improve meat quality of lambs [7, 8], rabbits [9] and pigs [10]. For example, diet supplement alfalfa can reduce cholesterol and increase polyunsaturated fatty acids in eggs [11], improve growth performance and carcass trait of lambs $[8,12]$. Alfalfa flavonoids, extracted from alfalfa, can promote meat quality and antioxidant activity by regulating the lipid metabolism-related genes expression in adipose and liver tissues [13].

Although CASF and alfalfa have been studied on the ruminant nutrition respectively, previous research focused on their application in dairy cows. However, earlier studies did not from the rumen microbial to study growth performance and meat quality of Holstein bulls, especially the additive effects between CASF and alfalfa. Consequently, the aim of this study was to evaluate the effects of CASF, alfalfa and their additive effects on apparent digestibility, rumen microbial flora, serum biochemical indexes, and meat quality of Holstein bulls.

\section{RESULTS}

\section{Alfalfa enhances growth performance and additive effect with CSFA on apparent digestibility of nutrients}

The effects of diets on growth, feed intake and nutrients apparent digestibility are shown in Table 1. Replacement Leymus chinensis with alfalfa significantly increased feed conversion ratio and average daily gain $(P<0.05)$. The apparent digestibility of dry matter (DM), acid detergent fiber (ADF) and organic matter (OM) in AN group was significantly higher than that in LN and $\mathrm{AC}$ group. And the apparent digestibility of DM and $\mathrm{OM}$ in LC group was significantly higher than that in LN group $(P<0.05)$. The apparent digestibility of crude protein $(\mathrm{CP})$ and neutral detergent fiber (NDF) in LC and AN diet were significantly higher than that in $\mathrm{LN}$ and $\mathrm{AC} \operatorname{diet}(P<0.05)$. There were significant additive effects between alfalfa and CSFA on apparent digestibility of DM, CP, NDF, ADF and OM $(P<0.05)$.

\section{CSFA increases serum low-density lipoprotein cholesterol concentrations}

As shown in Table 2, added CSFA in feed significantly increased concentrations of serum low-density lipoprotein cholesterol (LDL-C) $(P<0.05)$, and tended to increase cholesterol $(\mathrm{CHO})$ levels $(P=0.062)$. Serum alkaline phosphatase in $\mathrm{AC}$ group was significantly higher than that in LC group $(P<0.05)$. Replacing Leymus chinensis with alfalfa had a tendency to increase the activity of alkaline phosphatase (ALP) $(P=0.080)$. Serum urea concentration in LC group was significantly higher than that in LN and AC group $(P<0.05)$. There was significant additive effect between alfalfa and CSFA on serum urea $(P<0.05)$.

\section{Alfalfa and fat increase ammonia concentration and have additive effect in rumen fermentation}

The results of rumen fermentation characteristics are shown in Table 3. Replacement Leymus chinensis with alfalfa significantly reduced the concentrations of $\mathrm{NH}_{3}-\mathrm{N}$, acetate, isobutyrate, butyrate, total volatile fatty acid (TVFA) and Acetate/Propionate $(P<0.05)$, and increased the concentration of valerate $(P<0.05)$. The addition of CASF increased concentrations of ammoniacal nitrogen $\left(\mathrm{NH}_{3}-\mathrm{N}\right)$ isobutyrate, isovalerate and Acetate/Propionate in rumen $(P<0.05)$, and tended to raise valerate concentrations $(P=0.070)$. There were significant additive effects between alfalfa and CSFA on $\mathrm{NH}_{3}-\mathrm{N}$, acetate, isobutyrate, butyrate, isovalerate and TVFA $(P<0.05)$. The concentration of $\mathrm{NH}_{3}-\mathrm{N}$ in LC group was significantly higher than that in other three groups $(P<0.05)$, and AN group was significantly higher than that in AC three group $(P<0.05)$. Acetate concentration in AN diet was significantly lower than that of other diets $(P<0.05)$. The concentration of valerate and Acetate/Propionate in LN group was significantly higher than that in other three groups $(P<0.05)$. The isobutyrate and butyrate concentrations in LC diet were significantly higher than those in other diet $(P<0.05)$. And the isobutyrate in AN diet were significantly higher than those in LN and AC $\operatorname{diet}(P<0.05)$. The concentration of TVFA in LC group was significantly higher than that in $\mathrm{AC}$ group $(P<0.05)$.

\section{CASF reduces cooking loss of the Longissimus muscle}

Longissimus muscle, as one of the top grade beef, was used to describe the effects of various treatments on meat quality. Leymus chinensis and alfalfa had no impact on the meat quality (Table 4). CASF can significantly reduced cooking loss of the Longissimus muscle $(P<0.05)$. The cooking loss in AN group was significantly higher than that in $\mathrm{LN}$ and $\mathrm{AC}$ group $(P<0.05)$.

\section{AC group has the highest Alpha diversity of ruminal bacteria among diet treatments}

Total 32 samples were sequenced and reached 968470 high quality reads, average 30264 of each sample. When samples were normalized to 12556 reads depth, there generated 2237 operational taxonomic units (OTUs) by our analysis based on $97 \%$ similarity identity between reads. In order to estimate whether detected depth has 
reached the depth on behalf of rumen bacteria, the Good's coverage was calculated, which result revealed that the sequenced reads was able to describe at least $96.9 \%$ of the rumen bacterial community. Mean Alpha diversity index (Table 5) indicated that the shannon index, Observed species and PD whole tree of AC dietary treatment were significantly higher than those of LC treatment $(P<0.05)$; meanwhile, observed species of LN group was higher when compared with LC treatment $(P<0.05)$, and with no difference with AC dietary treatment. There were no significant differences for four groups of Chaol.

\section{Taxonomic composition of bacterial communities in rumen}

Based on $16 \mathrm{~S}$ bacterial ribosomal databases of Silva, 20 phyla were distinguished in the rumen bacteria of all samples (Figure 1 and Supplementary Table 1). In the mean of all samples, the abundance of 5 phyla was $>1 \%$, and the dominant phyla were Bacteroidetes and Firmicutes , which abundances were $62.56 \%$ and $31.07 \%$, respectively; the other 3 phyla abundance $>1 \%$ were Lentisphaerae (1.36\%), Proteobacteria (1.17\%) and Tenericutes (1.14\%). However, the other identified 15 phyla with relatively low abundance accounted for $2.72 \%$ of the total bacteria among all the samples, and the abundance of unidentified phyla accounted for $0.02 \%$ of the rumen bacterial flora. Kruskal-Wallis rank sum test was used to analysis of the significant differences between the diets group, the result indicated that the abundance of Bacteroidetes in LC diet was significantly higher than the other groups, but Spirochaetae in LC group was significantly lower than the other 3 groups $(P<0.05)$; the abundance of $S H A-109$ phylum in AN group was higher than the other 3 groups. At the genus level, $77.66 \%$ of the OTUs were identified and the taxonomic analysis indicated that there were 2 main genera in the rumen bacteria (Figure 2 and Supplementary Table 2). Prevotella_1 and Rikenellaceae_RC9_gut_group were the predominant genera accounting for $28.97 \%$ and $9.54 \%$ of the total samples, respectively. Moreover, there were 10 other relative abundance of genera is greater than $1 \%$. According to the Kruskal-Wallis rank sum test, 12 identified genera were significant differences in the 4 groups, including genus Treponema_2 which average relative abundance is greater than $0.5 \%$.

\section{No obviously clustered was observed among the groups by PCoA}

In this study, beta diversity was estimated by principal co-ordinates analysis (PCoA ) based on the weighted unifrac distances and shown that the samples with no obviously clustered according to dietary groups (Figure 3). PC1 and PC2 explained 59.33\% and $11.09 \%$ of variation, respectively.
Correlation between the relative abundances of ruminal bacterial genera and rumen fermentation characteristics, nutrients apparent digestibility, serum biochemical parameters

The rumen bacterial genera, which relative abundances were more than $0.1 \%$ in all 32 sequenced samples, were used to calculate correlation with other indicators, and the results were shown in Figure 4. In this present study, if the correlation coefficient $r>0.35$, we considered they were correlated with each other between the two indicators $(p<0.05)$. Valerate concentration in rumen had a strong negative correlation with the abundance of Ruminococcaceae_UCG-005 ( $r=-0.666$; $P<0.001)$. Butyrate had a strong positive correlation with the abundance of Butyrivibrio_2 ( $r=0.619$; $P<0.001) ; \mathrm{NH}_{3}-\mathrm{N}$ had a strong positive correlation with the abundance of Prevotella_1 $(r=0.667 ; P<0.001)$; while, it also had a strong negative correlation with the abundance of uncultured $(r=-0.569 ; P<0.001)$, Butyrivibrio_2 $(r=-0.556 ; P<0.001)$, Treponema_2 $(r=-0.598 ; P<0.001)$, Eubacterium_coprostanoligenes group $(r=-0.595 ; P<0.001)$, Prevotellaceae_NK3B31_ group $(r=-0.570 ; P<0.001)$, Ruminococcaceae_UCG$014(r=-0.761 ; P<0.001)$. ALT concentration in serum had a strong positive correlation with the abundance of Saccharofermentans $(r=0.556 ; P<0.001)$. Total protein (TP) concentration in serum had a strong positive correlation with the abundance of Ruminococcus_1 ( $r$ $=0.588 ; P<0.001)$. Albumin (ALB) concentration in serum had a strong positive correlation with the abundance of Succiniclasticum $(r=0.556 ; P<0.001)$. HDL-C concentration in serum had a strong positive correlation with the abundance of Ruminococcus_l $(r=0.567 ; P<0.001)$ and Ruminococcaceae_UCG-005 $(r=0.597 ; P<0.001)$. Aspartate aminotransferase (ASP) concentration in serum had a strong positive correlation with the abundance of Succiniclasticum $(r=0.677 ; P<0.001)$.

\section{DISCUSSION}

Rumen has an important role on physiological function in ruminants for the degradation of nutrients, especially plant fibers. Microbial fermentation in rumen was influenced by environmental, genetics and body condition of the host [14], which also directly or indirectly impact on the host to degrade, digest and absorb nutrients [15]. Therefore, the diet can alter the composition of rumen microorganisms, which potentially promote the growth of beef cattle. Fat deposition is the main purpose for beef cattle in the latter finishing period, therefore, feed with high energy density is often used during this period. In general, CASF and the alfalfa are usually used for dairy production, and the CASF as rumen-protected fat might be more conducive to fat deposition. However, limited studies have been carried out in beef production. So, the aim of this study is to assess the effects of CASF 
Table 1: Effect of dietary treatments on growth performance and digestibility of nutrients in Holstein bulls

\begin{tabular}{|c|c|c|c|c|c|c|c|c|c|}
\hline \multirow{2}{*}{ Item } & \multicolumn{4}{|c|}{ Dietary treatment } & \multirow{2}{*}{ SEM } & \multicolumn{4}{|c|}{$p$-value } \\
\hline & $\mathbf{L N}$ & $\mathbf{L C}$ & $\mathbf{A N}$ & $\mathbf{A C}$ & & Treatment & alfalfa & CSFA & alfalfa $\times$ CSFA \\
\hline Dry matter intake kg/d & 12.37 & 12.96 & 12.59 & 12.48 & 0.132 & 0.411 & 0.623 & 0.367 & 0.178 \\
\hline Feed conversion ratio & $11.23 \mathrm{a}$ & $11.25 \mathrm{a}$ & $8.87 \mathrm{~b}$ & $9.49 b$ & 0.203 & $<0.001$ & $<0.001$ & 0.380 & 0.410 \\
\hline Average daily gain & $1.21 \mathrm{a}$ & $1.16 \mathrm{a}$ & $1.42 \mathrm{~b}$ & $1.39 b$ & 0.083 & 0.001 & $<0.001$ & 0.412 & 0.897 \\
\hline \multicolumn{10}{|c|}{ Apparent digestibility of nutrients, $\%$} \\
\hline DM & $67.1 \mathrm{a}$ & $72.09 \mathrm{bc}$ & $72.67 \mathrm{c}$ & $69.17 \mathrm{ab}$ & 0.605 & 0.002 & 0.255 & 0.518 & 0.001 \\
\hline $\mathrm{CP}$ & $64.91 \mathrm{a}$ & $72.44 b$ & $72.28 \mathrm{~b}$ & $66.68 \mathrm{a}$ & 0.665 & $<0.001$ & 0.508 & 0.424 & $<0.001$ \\
\hline NDF & $56.17 \mathrm{a}$ & $64.95 b$ & $66.75 b$ & $56.06 \mathrm{a}$ & 1.01 & $<0.001$ & 0.648 & 0.604 & $<0.001$ \\
\hline $\mathrm{ADF}$ & $47.53 \mathrm{a}$ & $53.65 \mathrm{ab}$ & $57.43 b$ & $49.57 \mathrm{a}$ & 1.264 & 0.026 & 0.240 & 0.725 & 0.005 \\
\hline $\mathrm{EE}$ & 62.95 & 69.13 & 69.56 & 64.93 & 1.459 & 0.301 & 0.680 & 0.789 & 0.066 \\
\hline OM & $75.51 \mathrm{a}$ & $80.39 b c$ & $81.62 \mathrm{c}$ & $77.62 \mathrm{ab}$ & 0.651 & 0.003 & 0.182 & 0.725 & 0.001 \\
\hline
\end{tabular}

$\mathrm{LN}=$ Leymus as the only roughage with No calcium salts of fatty acid, LC $=$ Leymus as the only roughage with Calcium salts of fatty acids, AN $=$ Alfalfa replace $50 \%$ leymus with No calcium salts of fatty acids, $\mathrm{AC}=$ Alfalfa replace $50 \%$ leymus with Calcium salts of fatty acids.

OM, organic matter; CP, crude protein; NDF, neutral detergent fiber; ADF, acid detergent fiber; EE, ether extracts; DM: dry matter.

$p$-value: Treatment: $P$ value of Duncan's multiple comparisons between diets treatments and different lowercase letters within the same row denote significant differences between the treatments; alfalfa, CASF and alfalfa $\times$ CSFA: the factorial analysis of crude protein levels, CSFA and their interaction.

Table 2: Effects of dietarys on serum biochemical parameters of Holstein bulls

\begin{tabular}{|c|c|c|c|c|c|c|c|c|c|}
\hline \multirow{2}{*}{ Item } & \multicolumn{4}{|c|}{ Dietary treatment } & \multirow{2}{*}{ SEM } & \multicolumn{4}{|c|}{$p$-value } \\
\hline & $\mathbf{L N}$ & LC & $\mathbf{A N}$ & AC & & Treatment & alfalfa & CSFA & alfalfa $\times$ CSFA \\
\hline Glucose $(\mathrm{mmol} / \mathrm{L})$ & 5.14 & 4.94 & 4.99 & 4.89 & 0.097 & 0.831 & 0.635 & 0.450 & 0.809 \\
\hline Triglyceride $(\mathrm{mmol} / \mathrm{L})$ & 0.16 & 0.17 & 0.14 & 0.15 & 0.009 & 0.719 & 0.338 & 0.585 & 0.759 \\
\hline Cholesterol (mmol/L) & 2.36 & 3.4 & 2.87 & 3.68 & 0.235 & 0.232 & 0.411 & 0.062 & 0.808 \\
\hline Alanine transaminase $(\mathrm{U} / \mathrm{L})$ & 21.24 & 19.81 & 19.33 & 21.11 & 1.39 & 0.956 & 0.917 & 0.951 & 0.587 \\
\hline Total protein $(\mathrm{g} / \mathrm{L})$ & 48.69 & 44.51 & 47.23 & 44.78 & 2.93 & 0.955 & 0.923 & 0.593 & 0.889 \\
\hline Albumin $(\mathrm{g} / \mathrm{L})$ & 26.58 & 25.44 & 28.56 & 24.05 & 1.405 & 0.729 & 0.918 & 0.337 & 0.564 \\
\hline Urea $(\mathrm{mmol} / \mathrm{L})$ & $3.78 \mathrm{ab}$ & $5.06 \mathrm{c}$ & $4.61 \mathrm{ac}$ & $3.65 b$ & 0.183 & 0.010 & 0.357 & 0.621 & 0.001 \\
\hline HDL-C (mmol/L) & 1.47 & 1.7 & 1.55 & 1.8 & 0.123 & 0.801 & 0.736 & 0.355 & 0.955 \\
\hline LDL-C (mmol/L) & 1.37 & 1.99 & 1.68 & 2.08 & 0.117 & 0.117 & 0.370 & 0.028 & 0.636 \\
\hline Alkaline phosphatase (U/L) & $165.8 \mathrm{ab}$ & $122.1 \mathrm{a}$ & $164.4 \mathrm{ab}$ & $180.0 \mathrm{~b}$ & 8.35 & 0.073 & 0.080 & 0.376 & 0.067 \\
\hline Aspartate aminotransferase (U/L) & 0.16 & 0.13 & 0.12 & 0.12 & 0.01 & 0.492 & 0.310 & 0.327 & 0.529 \\
\hline
\end{tabular}

$\mathrm{LN}=$ Leymus as the only roughage with No calcium salts of fatty acid, $\mathrm{LC}=$ Leymus as the only roughage with Calcium salts of fatty acids, $\mathrm{AN}=\mathrm{Alfalfa}$ replace $50 \%$ leymus with No calcium salts of fatty acids, $\mathrm{AC}=$ Alfalfa replace $50 \%$ leymus with Calcium salts of fatty acids.

LDL-C, low-density lipoprotein cholesterol; HDL-C, high-density lipoprotein cholesterol.

$p$-value: Treatment: $P$ value of Duncan's multiple comparisons between diets treatments aund different lowercase letters within the same row denote significant differences between the treatments; alfalfa, CASF and alfalfa $\times$ CSFA: the factorial analysis of crude protein levels, CSFA and their interaction.

and alfalfa in beef cattle production, including growth, feed intake, apparent digestibility, serum biochemical parameters, rumen fermentation characteristics as well as bacterial communities.

Alfalfa supplementation improved feed conversion ratio with no effect on DM intake in the present study, and reduced the formation of acetate and butyrate fermentation in the rumen. That means more nutrients directly passed the rumen without fermentation, leading the higher nutrient digestion and absorption in digestive tract. However, alfalfa used in this experiment had high $\mathrm{ADF}$, which caused that the digestive enzymes cannot combine with substrates, consequently, resulted in alfalfa had no significant effect on apparent digestibility of nutrients. The alfalfa diet did not improve the meat quality of Longissimus, which were in similar results with other studies $[8,16]$. Fiber-degrading bacteria can use ammonia as the nitrogen sources for growth [17]. Increasing the concentration of ammonia in the rumen is conducive to bacterial growth, which is beneficial for cellulose fibers to produce acetate and butyrate [18]. This is why alfalfa reduced the concentration of $\mathrm{NH}_{3}-\mathrm{N}$ and also acetate, butyrate, TVFA and Acetate/Propionate in rumen.

Fatty acids are absorbed in the duodenum [19] and improved the growth performance, meat quality and health of beef cattle. Generally, dietary fat can reduce dry matter intake, nutrients apparent digestibility, particular digestibility of crude fiber, because high fat diets has 
Table 3: Effect of dietarys on rumen fermentation of Holstein bulls

\begin{tabular}{|c|c|c|c|c|c|c|c|c|c|}
\hline \multirow{2}{*}{ Item } & \multicolumn{4}{|c|}{ Dietary treatment } & \multirow[b]{2}{*}{ SEM } & \multicolumn{4}{|c|}{$p$-value } \\
\hline & $\mathbf{L N}$ & LC & AN & $\mathbf{A C}$ & & Treatment & alfalfa & CSFA & alfalfa $\times$ CSFA \\
\hline $\mathrm{NH}_{3}-\mathrm{N}(\mathrm{mg} / \mathrm{dL})$ & $6.01 \mathrm{ac}$ & $9.86 \mathrm{~b}$ & $6.8 \mathrm{c}$ & $5.2 \mathrm{a}$ & 0.344 & $<0.001$ & 0.0007 & 0.0394 & $<0.001$ \\
\hline $\mathrm{pH}$ & 6.11 & 6.01 & 6.09 & 5.99 & 0.0329 & 0.5106 & 0.7812 & 0.139 & 0.9212 \\
\hline \multicolumn{10}{|l|}{ VFA (mmol/L) } \\
\hline Acetate & $67.15 \mathrm{a}$ & $67.86 \mathrm{a}$ & $64.87 \mathrm{a}$ & $59.44 b$ & 0.739 & $<0.001$ & $<0.001$ & 0.088 & 0.027 \\
\hline Propionate & 14.11 & 15.75 & 15.49 & 16.61 & 0.42 & 0.209 & 0.184 & 0.101 & 0.757 \\
\hline Isobutyrate & $0.47 \mathrm{a}$ & $0.56 \mathrm{~b}$ & $0.51 \mathrm{c}$ & $0.48 \mathrm{a}$ & 0.005 & $<0.001$ & 0.027 & 0.002 & $<0.001$ \\
\hline Butyrate & $10.8 \mathrm{ab}$ & $13.0 \mathrm{c}$ & $11.7 \mathrm{a}$ & $10.1 \mathrm{~b}$ & 0.19 & $<0.001$ & 0.003 & 0.360 & $<0.001$ \\
\hline Isovalerate & $1.07 \mathrm{a}$ & $1.26 \mathrm{~b}$ & $1.17 \mathrm{c}$ & $1.15 \mathrm{c}$ & 0.014 & $<0.001$ & 0.991 & 0.001 & $<0.001$ \\
\hline Valerate & $0.56 \mathrm{a}$ & $0.66 b$ & $0.68 \mathrm{~b}$ & $0.68 b$ & 0.014 & 0.004 & 0.010 & 0.070 & 0.056 \\
\hline TVFA & $94.18 \mathrm{ab}$ & $99.08 \mathrm{a}$ & $94.38 \mathrm{ab}$ & $88.46 \mathrm{~b}$ & 1.09 & 0.007 & 0.015 & 0.810 & 0.011 \\
\hline $\begin{array}{l}\text { Acetate/ } \\
\text { Propionate }\end{array}$ & $4.8 \mathrm{a}$ & $4.35 \mathrm{~b}$ & $4.25 b$ & $4.05 b$ & 0.066 & 0.001 & 0.001 & 0.010 & 0.315 \\
\hline
\end{tabular}

$\mathrm{LN}=$ Leymus as the only roughage with No calcium salts of fatty acid, LC = Leymus as the only roughage with Calcium salts of fatty acids, $\mathrm{AN}=$ Alfalfa replace $50 \%$ leymus with No calcium salts of fatty acids, $\mathrm{AC}=$ Alfalfa replace $50 \%$ leymus with Calcium salts of fatty acids.

$p$-value: Treatment: $P$ value of Duncan's multiple comparisons between diets treatments and different lowercase letters within the same row denote significant differences between the treatments; alfalfa, CASF and alfalfa $\times$ CSFA: the factorial analysis of crude protein levels, CSFA and their interaction.

Table 4: Effect of dietarys on quality traits of Longissimus muscle

\begin{tabular}{|c|c|c|c|c|c|c|c|c|c|}
\hline \multirow{2}{*}{ Item } & \multicolumn{4}{|c|}{ Dietary treatment } & \multirow{2}{*}{ SEM } & \multicolumn{4}{|c|}{$p$-value } \\
\hline & $\mathbf{L N}$ & $\mathbf{L C}$ & $\mathbf{A N}$ & $\mathbf{A C}$ & & Treatment & alfalfa & CSFA & alfalfa $\times$ CSFA \\
\hline Shear force, $\mathrm{kg}$ & 4.35 & 3.88 & 4.18 & 4.28 & 0.133 & 0.619 & 0.667 & 0.481 & 0.297 \\
\hline Cooking loss, $\%$ & $33.7 \mathrm{ab}$ & $32.5 \mathrm{a}$ & $35.7 \mathrm{~b}$ & $31.2 \mathrm{a}$ & 0.509 & 0.010 & 0.679 & 0.004 & 0.089 \\
\hline Water holding capacity, $\%$ & 55.5 & 53.5 & 54.0 & 54.4 & 0.606 & 0.711 & 0.805 & 0.535 & 0.338 \\
\hline Drip loss, $\%$ & 6.53 & 6.75 & 6.43 & 6.91 & 0.112 & 0.439 & 0.900 & 0.126 & 0.569 \\
\hline Dry matter, \% & 26.5 & 26.6 & 26.3 & 26.9 & 0.182 & 0.658 & 0.833 & 0.325 & 0.447 \\
\hline Crude protein, \% DM & 83.2 & 83.0 & 82.8 & 83.1 & 0.165 & 0.835 & 0.650 & 0.908 & 0.427 \\
\hline Intramuscular fat, \% DM & 14.6 & 14.9 & 15.0 & 14.8 & 0.171 & 0.858 & 0.683 & 0.920 & 0.447 \\
\hline
\end{tabular}

$\mathrm{LN}=$ Leymus as the only roughage with No calcium salts of fatty acid, $\mathrm{LC}=$ Leymus as the only roughage with Calcium salts of fatty acids, $\mathrm{AN}=$ Alfalfa replace $50 \%$ leymus with No calcium salts of fatty acids, $\mathrm{AC}=$ Alfalfa replace $50 \%$ leymus with Calcium salts of fatty acids.

$p$-value: Treatment: $P$ value of Duncan's multiple comparisons between diets treatments and different lowercase letters within the same row denote significant differences between the treatments; alfalfa, CASF and alfalfa $\times$ CSFA: the factorial analysis of crude protein levels, CSFA and their interaction.

adversely influence on rumen microorganism [1,20]. The CSFA as a rumen-protected fat had no effect on the apparent digestibility of nutrients in the present study. However, the CASF can inhibit the rumen fermentation and reduce the ratio of Acetate/Propionate, which is consistent with studies on the dairy [19]. Simultaneously, we also found that the CASF can increase the branchedchain volatile fatty acid (isobutyrate and isovalerate), which are generated by rumen fermentation and decomposition of branched-chain amino acids. The reason for this result was that the CASF increased $\mathrm{NH}_{3}-\mathrm{N}$ concentration in rumen and changed the characteristics of rumen microbial fermentation [21]. In serum biochemistry, CASF can increase the concentration of cholesterol and triglyceride in the liver through the synthesis of fat metabolism [3], which can elevate serum cholesterol levels. We observed that it significantly increased LDL-C content, which indicated that the CASF supplementation is detrimental to the health of cattle, because of increasing the risk of atherosclerosis.

Compared with LN group, the increases in the apparent digestibility of DM, CP, NDF and OM in LC group were the results of that CASF is a salt, which are not completely inert in the rumen, and can release a part of fatty acids in 
Table 5: Mean richness estimates for dietarys

\begin{tabular}{|c|c|c|c|c|c|c|}
\hline \multirow{2}{*}{ Item } & \multicolumn{4}{|c|}{ Dietary treatment } & \multirow{2}{*}{ SEM } & \multirow{2}{*}{$P$-value } \\
\hline & LN & $\mathrm{LC}$ & AN & $\mathrm{AC}$ & & \\
\hline Shannon index & $8.10 \mathrm{ab}$ & $7.79 a$ & 7.98ab & $8.27 b$ & 0.06 & 0.029 \\
\hline Observed species & $1137.64 \mathrm{a}$ & $1029.2 b$ & $1087.03 \mathrm{ab}$ & $1155.46 \mathrm{a}$ & 17.96 & 0.0498 \\
\hline Chao1 & 1482.25 & 1380.9 & 1434.42 & 1491.17 & 19.22 & 0.154 \\
\hline PD whole tree & $94.04 \mathrm{ab}$ & $88.02 \mathrm{a}$ & $91.81 \mathrm{ab}$ & $95.99 \mathrm{~b}$ & 1.23 & 0.043 \\
\hline
\end{tabular}

Even sampling depth based on sample with the lowest number of sequences (12556).

$\mathrm{LN}=$ Leymus as the only roughage with No calcium salts of fatty acid, $\mathrm{LC}=$ Leymus as the only roughage with Calcium salts of fatty acids, $\mathrm{AN}=$ Alfalfa replace $50 \%$ leymus with No calcium salts of fatty acids, $\mathrm{AC}=$ Alfalfa replace $50 \%$ leymus with Calcium salts of fatty acids.

$p$-value: $P$ value of Duncan's multiple comparisons between diets treatments and different lowercase letters within the same row denote significant differences between the treatments.

the rumen, then interacting with the rumen environment and being hydrogenated by rumen microorganism [22]. This mechanism is not caused by the increase of calcium in diets, possibly because that the CSFA increased the proportion of $\mathrm{C} 16: 0$ in the diet which was not harmful to rumen microbes, while the unsaturated fatty acids in CASF can improve cholecystokinin release in the intestine [23]. They led to increased digestibility of nutrients, but no effect on ADF apparent digestibility. Dietary supplementation of fat is beneficial to the energy and nitrogen balance of ruminant, which contributes to the fermentation of rumen [24]. Moreover, the CSFA can effectively avoid the harmful effects of fatty acids on cellulolytic bacteria.

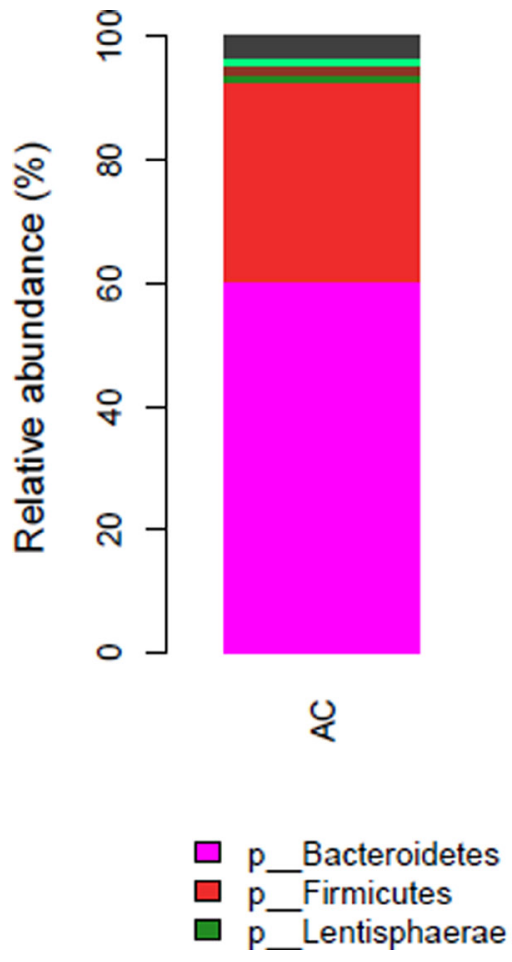

Alfalfa instead of Leymus chinensis increased fiber content in diets, which was not conducive to the combination of digestive enzymes and substrates, and hindered the combination of calcium and fatty acids released from fatty acid calcium salts. The results showed that the alfalfa and CSFA had antagonistic additive effects on apparent digestibility of nutrients. At the same time, this antagonistic effect also inhibited the rumen fermentation, because these released fatty acids can restrain the fermentation of microorganisms, fatty acids inhibited the growth of fiberdegrading bacteria and reduced the production of acetic acid.

Fatty acids are absorbed into the intestinal cells and blood, which is inseparable from the transport

Figure 1: Effect of dietary treatments on phylum relative abundance of the ruminal bacterial community. $N=8$ for each treatment. $\mathrm{LN}=$ Leymus as the only roughage with No calcium salts of fatty acid, $\mathrm{LC}=$ Leymus as the only roughage with Calcium salts of fatty acids, $\mathrm{AN}=$ Alfalfa replace $50 \%$ leymus with No calcium salts of fatty acids, $\mathrm{AC}=$ Alfalfa replace $50 \%$ leymus with Calcium salts of fatty acids 


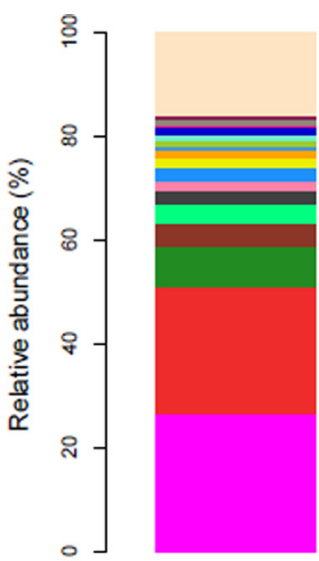

$\mathrm{AC}$

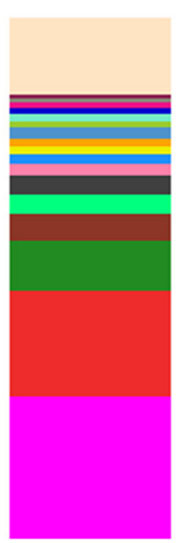

AN

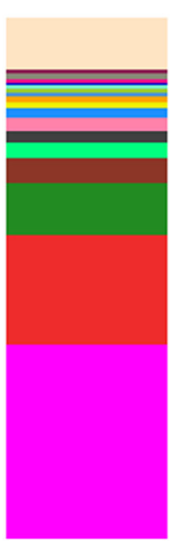

LC

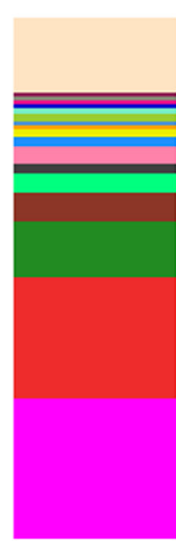

LN

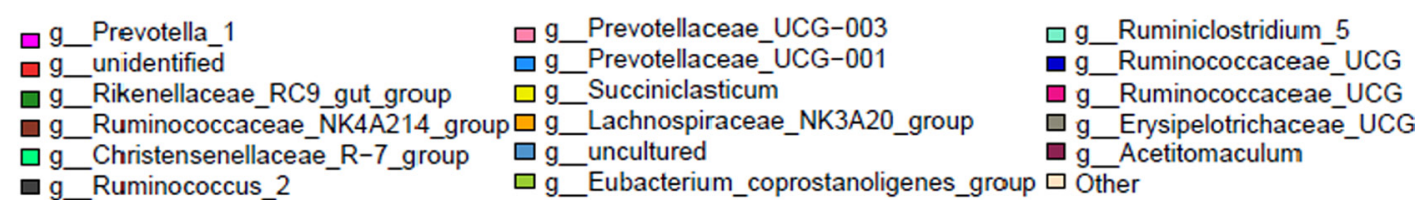

Figure 2: The effects of dietary treatments on the Genus (the relative abundance) of the ruminal bacterial community. $N=8$ for each treatment. $\mathrm{LN}=$ Leymus as the only roughage with No calcium salts of fatty acid, $\mathrm{LC}=$ Leymus as the only roughage with Calcium salts of fatty acids, $\mathrm{AN}=$ Alfalfa replace $50 \%$ leymus with No calcium salts of fatty acids, $\mathrm{AC}=\mathrm{Alfalfa}$ replace $50 \%$ leymus with Calcium salts of fatty acids.

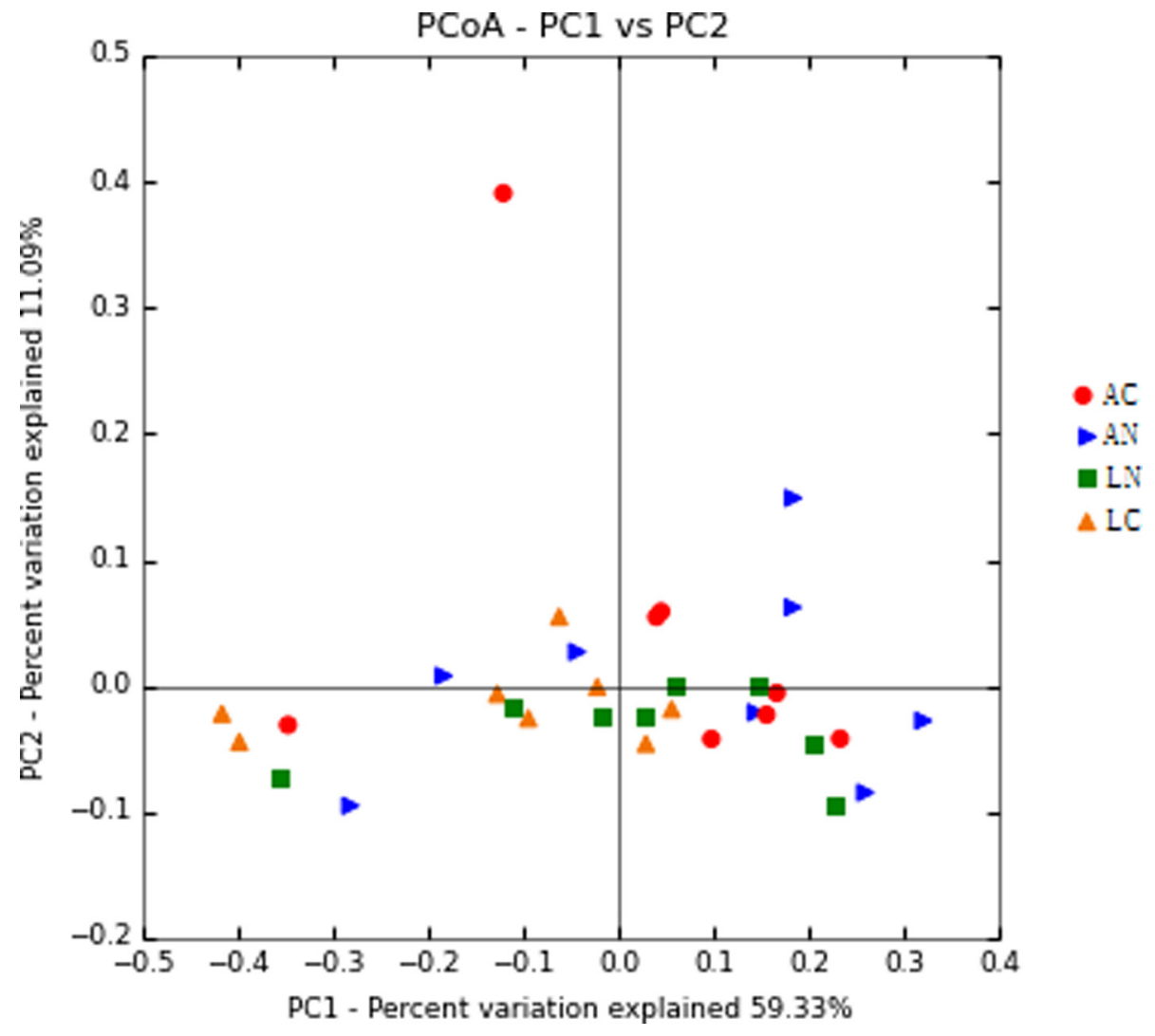

Figure 3: Principal Coordinate Analysis (PCoA) of rumen bacterial community structures of the four dietary treatments. The PCoA plots were constructed using the weighted UniFrac method. $N=8$ for each treatment. $\mathrm{LN}=$ Leymus as the only roughage with No calcium salts of fatty acid, $\mathrm{LC}=$ Leymus as the only roughage with Calcium salts of fatty acids, AN = Alfalfa replace $50 \%$ leymus with No calcium salts of fatty acids, $\mathrm{AC}=$ Alfalfa replace $50 \%$ leymus with Calcium salts of fatty acids. 
of lipoprotein, especially long-chain fatty acid transport needs more lipoprotein transport system for mobilization [25]. The synthesis of lipoproteins requires the absorption of amino acids, which has similar protein levels in the treatment group, and therefore, dietary supplementation of CSFA increased the amino acids requirements for the synthesis of lipoproteins. The fatty acid absorption has synergism to amino acids absorption.
In this study, Good's coverage of all samples was evaluated and reached 0.967 , which indicated that the study has covered $96.7 \%$ OTU calculated in a $97 \%$ similarity. Because diets are major factors on the rumen microbial fermentation [26], then this research just directly compared four diets on rumen microbial effects, without using factorial analysis to individually assess the effects of alfalfa, CASF and their additive effects, respectively. Alpha diversity indices revealed a higher diversity in AC

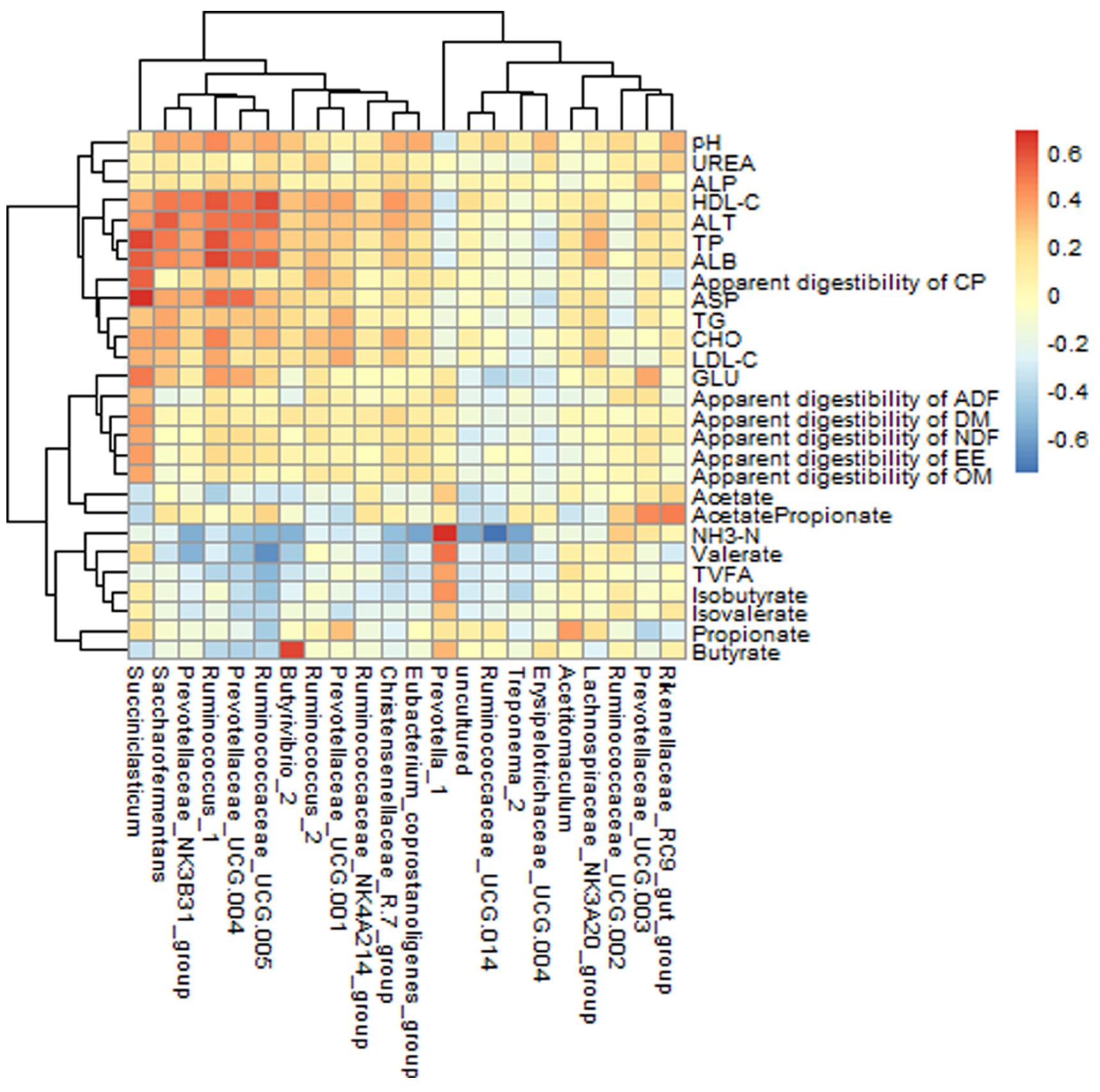

Figure 4: Correlation between bacterial genus abundance and rumen fermentation characteristics, nutrients apparent digestibility, serum biochemical parameters. $N=32$ for each point. Only the predominant bacterial genera (relative abundance $\geq 0.1 \%$ in each sample) are presented; Cells are colored based on spearman rank correlation test between rumen bacteria and rumen fermentation characteristics, nutrients apparent digestibility, serum biochemical parameters. The red color represents a positive correlation, the blue color represents a negative correlation. 
diet compared to LC diet. However, the diversity between LN and AN diets had no difference, which suggested that different combinations of feed ingredients produced different biodiversity in rumen even though they have similar nutritional composition, and that $\mathrm{AC}$ and $\mathrm{LC}$ dietary treatments hosted a distinct bacterial community with regard to bacterial makeup. However, in our study, the nutrients in the diet of various groups are equal except to adding calcium salts of fatty acids, which led that there were no significantly cluster among 4 treatment groups of beta diversity estimated by PCoA and proved they have similar bacterial community.

Bacteria as the main composition of gastrointestinal microbes [27], plays an important role on the rumen function. It synthesized necessary amino acids and vitamins with non-protein nitrogen, and generated volatile fatty acids by decomposing cellulose and starch to provide energy to the host [28]. Therefore, the rumen bacterium as a complex micro-ecological composition, changes of diet can impact rumen microbial metabolism, ultimately changing host performance and product quality. The composition of rumen bacteria community showed that the bacterial community was predominated by Bacteroidetes and Firmicutes, which distributed similarly with Jami [29], and Bacteroidetes has the highest relative abundance than the others. But behind the two dominant phyla the others variation is very large. Generally, Proteobacteria is the third-largest phylum in the rumen $[29,30]$, but it was ranked behind Lentisphaerae in this study. However, Zhang et al. [31] found that the Tenericutes is the thirdlargest phylum. Such different results may be due to the relative abundance of these phyla are very small, and vulnerable to diets and the effects of other factors. At the phylum level, Bacteroidetes relative abundance of LC group was significantly higher than AN group, because their diet composition are differences in maximum, and fatty acids can inhibit the growth of numerous bacteria [32]; meanwhile, it also means that exists additive effects between alfalfa and CASF. It is generally believed that a greater diversity of rumen microbes flora are benefit for the stable of rumen environment [33], suggesting that LC dietary was more advantageous to stability of rumen micro-ecological environment.

At genus level, in the relative abundance of more than $1 \%$ bacteria, there were no significant differences among the four diets groups, meanwhile, PCoA also verified that one of the results. All available reports suggested that Prevotella genus is the dominant ruminal genus in abundance [26, 34], indicating that Prevotella is stable in the rumen and not easily influenced by experimental factors. Stevenson et $a l$. reported that it has the rate-limiting performance of dipeptidase activity [35], suggesting it takes charge of hydrolysis oligopeptides. Therefore, Prevotella has an important role in degradation of protein in rumen, especial in breakdown dipeptide. In this study, Rikenellaceae $R C 9$ was included in the most abundant ruminal bacteria genera. Ruminococcus and Fibrobacter genera belong to Firmicutes phylum have the function of cellulosis [26]. The relative abundance of Ruminococcus genus accounts for $2.52 \%$ of all the rumen bacteria regardless of dietary treatments, which fits with the results of Bainbridge et al., who showed that Ruminococcus accounts for $2.59 \%$ of bacteria in rumen of Holstein cows. However, there were different reports that the level was higher [36] or lower [26] than this level. Ruminococcaceae family contains several genera, in which Ruminococcaceae_NK4A214_group with the highest relative abundance and about $5.1 \%$ of total bacteria. Whereas, Prevotellaceae_UCG-003 genus and Prevotellaceae_UCG-001 genus are part of Prevotellaceae family which belong to Bacteroidetes phylum and have the function of breakdown hemicellulose and protein [37]. Succiniclasticum genus, which belongs to Firmicutes phylum can generate propionate by degrading the succinate [38]; and it represented about $1.52 \%$ of total bacteria in this study. As a whole, dominant microflora as main performer in rumen fermentation and were not significantly different among the four treatment groups, eventually led to the apparent digestibility of nutrients in the diet had no significant difference.

It has been reported that host serum biochemical index, immunization and health were influenced by the gastrointestinal tract microorganisms [39, 40]; meanwhile, microbial structure, function and abundance work on the host's phenotype. In terms of rumen fermentation characteristics, there were extremely significant correlations between rumen $\mathrm{NH}_{3}-\mathrm{N}$ concentration and variety of Bacterial genera, because $\mathrm{NH}_{3}-\mathrm{N}$ is wholly generated and utilized by microbial metabolism in rumen. Such as $\mathrm{NH}_{3}-\mathrm{N}$ was significantly positively correlated with Prevotella_l genus, because of its degradation protein activity was advantageous to produce $\mathrm{NH}_{3}-\mathrm{N}$; however, Butyrivibrio 2, Prevotellaceae NK3B31 group and Ruminococcaceae_UCG-014 genera as degradation of cellulose and hemicellulose bacteria, which can synthesis bacterial protein by using non-protein nitrogen, and resulting in them was negatively correlated with the $\mathrm{NH}_{3}-\mathrm{N}$ concentration. Similarly, Butyrivibrio_2 genus can produce butyrate by the degradation of plant cellulose and starch in the rumen. Because it can generate mucosal butyrate and release butyrate close to the epithelial tissue, and enhance biological availability of butyrate for the ruminant [41], thus, there was a significant positive correlation between Butyrivibrio_2 genus and butyrate. Serum biochemical parameters associated with many bacterial genera in the rumen in this study. There was no evidence for rumen bacteria directly act on the serum biochemical parameters. The possible causes of this correlation is that the degradation products of rumen bacteria through the hepatic metabolism to change serum biochemical parameters.

In summary, alfalfa supplementation can improve feed conversion ratio during the finishing period of beef 
cattle. Dietary CASF increased the content of serum LDL-C, and reduced the cooking loss of beef. CASF and the alfalfa altered rumen fermentation, while had no significant effects on apparent digestibility of nutrients. Alfalfa and CASF had significant additive effects on the apparent digestibility of nutrients and rumen fermentation. In rumen bacteria, compared with additional alfalfa, dietary adding CASF increased microbial diversity index, but no significant difference in bacteria abundance at the genus level was found among the four dietary treatments. In correlation analysis, the relative abundances of rumen bacterial genera not only had correlation with apparent digestibility of nutrients and rumen fermentation characteristics, but also had correlation with serum biochemical parameters. Overall, the results of this study suggested that the application of CASF and alfalfa would be beneficial in beef cattle production.

\section{MATERIALS AND METHODS}

\section{Ethical approval}

The cattle experiment was approved by the Ethics Committee of China Agricultural University (Permit No. DK1008), and in accordance with the guidelines and regulations that enacted by the Administration of Affairs Concerning Experimental Animals.

\section{Experimental design and animal diet}

A total of 48 Holstein bulls at 20 months of age were selected and randomly divided into four treatments. Each treatment contained 12 bulls. From birth to beginning of this trial, these bulls received the same diet. One of four diets provided to each group: 1) basic diet: Leymus chinensis as the only roughage with no $\mathrm{CASF}(\mathrm{LN}) ; 2$ ) alfalfa replace 50\% Leymus chinensis with no CASF(AN); 3) basic diet with $2.4 \% \mathrm{CASF}(\mathrm{LC})$; 4) Alfalfa replace $50 \%$ Leymus chinensis with $2.4 \%$ calcium salts of fatty acid (AC). Feed formula and nutrition components of the trial are shown in Table 6. All cattle were fed twice a day at 7:30 and 17:30, respectively. All animals were fed ad libitum and allowed about $10 \%$ orts each day, feed intake was recorded every day. Fresh drinking water was offered free-choice at all times. During the 90 days trial period, body weight of cattle was recorded monthly. Feed intakes and orts were recorded daily.

\section{Samples collection and treatment}

Feed and orts samples were collected monthly. Feces were gathered at 6:00, 12:00, 18:00 and 24:00 on continuous 3 days, and 10\% tartaric acid solution was added into the feces, 65 . Approximate $10 \mathrm{~mL}$ of blood was collected through jugular vein at 7:00 in the morning, then centrifuged at $3000 \mathrm{~g}$ for $15 \mathrm{~min}$ to collect supernatant serum and stored at $-20^{\circ} \mathrm{C}$. Two hours after the morning feeding, $100 \mathrm{~mL}$ ruminal fluid was collected by using esophageal tubing and discarded the first $300 \mathrm{~mL}$ to avoid cross contamination of saliva and the samples. All cattle were slaughtered at the end of the feeding experiment. After chilled $4^{\circ} \mathrm{C}$ for 48 hours, about $500 \mathrm{~g}$ and $5 \mathrm{~cm}$ length of Longissimus muscle were taken at the left halfcarcass between the 6 and 7 ribs.

\section{Chemical analysis of samples}

The ether extract (EE), DM, crude ash and CP of feed, orts and feces were analyzed by using the methods of AOAC [42]. Acid-insoluble ash was measured according to previous methods [43], and used as an endogenous indicator to calculate the apparent digestibility of nutrients. Glucose (GLU), cholesterol, alanine transaminase (ALT), total protein, albumin, urea, high density lipoprotein cholesterol, low density lipoprotein cholesterol, alkaline phosphatase and aspartate aminotransferase (ASP) of serum were measured by Automatic biochemical Analyzer (HITACHI 7020, Tokyo, Japan) and the corresponding kits (Strong Biotechnologies Inc, Beijing, China). Volatile fatty acids (VFA) of rumen fluid were tested by gas chromatography (Shimadzu GC-2014, Kyoto, Japan), and referenced the prior conditions [44]. The $\mathrm{NH}_{3}-\mathrm{N}$ concentration in the rumen liquid was determined according to previous methods [45] using a spectrophotometer (UV-1700, Shimadzu Corporation, Kyoto, Japan)

A total of 32 rumen content samples, randomly selected 8 Holstein bulls from each group, were collected at 10:00 via esophageal tubing [30]. The 16sDNA of rumen content samples were extracted using the bacterial DNA Kit (Omega Bio-Tek, Norcross, GA, USA) according to the manufacturer's protocol. DNA concentration and purity were determined on a UV1700 spectrophotometer (Shimadzu, Kyoto, Japan). The V3-V4 region of the bacteria 16S rRNA gene were amplified with the universal primers of the forward 338 F(5'-ACTCCTACGGGAGGCAGCAG-3') and the reverse 806R (5'-GGACTACHVGGGTWTCTAAT-3'), and subjected to high-throughput sequencing by Beijing Allwegene Tech, Ltd (Beijing, China) using the Illumina Miseq PE300 sequencing platform (Illumina, Inc., CA, USA). These primers contained a set of 8-nucleotide barcodes sequence unique to each sample. The PCR program was as follows $95^{\circ} \mathrm{C}$ for $5 \mathrm{~min}, 25$ cycles at $95^{\circ} \mathrm{C}$ for $30 \mathrm{~s}, 55^{\circ} \mathrm{C}$ for $30 \mathrm{~s}$, and $72^{\circ} \mathrm{C}$ for $30 \mathrm{~s}$ with a final extension of $72^{\circ} \mathrm{C}$ for $10 \mathrm{~min}$. DNA amplification products were retrieved by $2 \%$ agarose gels and purified using the AxyPrep DNA Gel Extraction Kit (Axygen Biosciences, Union City, CA, U.S.) according to the manufacturer's instructions and quantified using QuantiFluor ${ }^{\mathrm{TM}}$-ST (Promega Corporation, Madison, WI, U.S.). Purified 
Table 6: Ingredients and nutrient compositions of the dietary treatments ${ }^{1}$

\begin{tabular}{|c|c|c|c|c|}
\hline Item & $\mathbf{L N}$ & $\mathbf{L C}$ & $\mathbf{A N}$ & $\mathrm{AC}$ \\
\hline \multicolumn{5}{|l|}{ Ingredient, \% (DM basis) } \\
\hline corn grain & 40.44 & 39.47 & 38.16 & 37.24 \\
\hline soybean meal & 8.22 & 8.02 & 6.72 & 6.56 \\
\hline wheat grain & 9.84 & 9.6 & 13.62 & 13.29 \\
\hline Leymus chinensis & 40 & 39.04 & 20 & 19.52 \\
\hline Alfalfa & 0 & 0 & 20 & 19.52 \\
\hline Calcium salt of fatty acids & 0 & 2.4 & 0 & 2.4 \\
\hline $\mathrm{NaCl}$ & 0.6 & 0.59 & 0.6 & 0.59 \\
\hline Mineral-vitamin premix ${ }^{2}$ & 0.6 & 0.59 & 0.6 & 0.59 \\
\hline limestone & 0.3 & 0.29 & 0.3 & 0.29 \\
\hline \multicolumn{5}{|c|}{ Chemical composition, \% (DM basis) } \\
\hline $\mathrm{OM}$ & 94.07 & 93.18 & 94.26 & 93.72 \\
\hline $\mathrm{CP}$ & 12.84 & 12.54 & 12.42 & 12.16 \\
\hline NDF & 42.63 & 42.96 & 42.45 & 42.91 \\
\hline $\mathrm{ADF}$ & 18.4 & 18.26 & 21.01 & 20.94 \\
\hline $\mathrm{EE}$ & 6.71 & 6.69 & 6.48 & 6.5 \\
\hline \multicolumn{5}{|c|}{ Main fatty acids profile, $\%$ of total } \\
\hline $\mathrm{C} 16: 0$ & 16.8 & 28.4 & 17.1 & 28.2 \\
\hline C18:0 & 2.7 & 3.2 & 2.6 & 3.3 \\
\hline C18:1n-9 cis & 26.3 & 27.8 & 26.3 & 27.8 \\
\hline $\mathrm{C} 18: 2 \mathrm{n}-6$ cis & 49.3 & 36.0 & 49.1 & 36.0 \\
\hline C20:1 & 3.3 & 2.7 & 3.1 & 2.6 \\
\hline
\end{tabular}

${ }^{1}$ Dietary treatments: $\mathrm{LN}=$ Leymus as the only roughage with No calcium salts of fatty acid, LC $=$ Leymus as the only roughage with Calcium salts of fatty acids, $\mathrm{AN}=$ Alfalfa replace $50 \%$ leymus with No calcium salts of fatty acids, $\mathrm{AC}=$ Alfalfa replace $50 \%$ leymus with Calcium salts of fatty acids.

${ }^{2}$ Every kilogram of mineral-vitamin premix contained: 1000000 IU Vitamin A, 350000 IU Vitamin D3, 5.7 g Zn, 4.2 g Fe, $5.72 \mathrm{~g} \mathrm{Mn}, 2.5 \mathrm{~g} \mathrm{Cu}, 85 \mathrm{mg} \mathrm{I}, 85 \mathrm{mg} \mathrm{Se}$, and $30 \mathrm{mg}$ Co.

$\mathrm{OM}$, organic matter; $\mathrm{CP}$, crude protein; NDF, neutral detergent fiber; ADF, acid detergent fiber; EE, ether extracts; DM: dry matter.

amplicons were pooled in equimolar and paired-end sequenced $(2 \times 300)$ on an Illumina MiSeq platform (San Diego, CA, USA) according to the standard protocols.

\section{Processing of sequencing data}

Raw quality control of the generated sequences was executed by using the Trimmomatic and Usearch Software, which included trimming of the $3^{\prime}$ end of sequences that dropped below the average 20 score over a $50 \mathrm{bp}$ and removing sequences with unidentified bases, while chimeric sequences were identified and removed using Usearch Version 8.1.1861 in the method of UPARSE [46]. Resulting sequences were demultiplexed using the QIIME software package (version 1.9.1) [47]. Subsequently, sequences were binned into OTUs at $97 \%$ similarity using the UPARSE pipeline (USEARCH
Version 8.1.1861) [46]. Representative sequences from each OTU were assigned taxonomy by using the RDP Classifier [48] method against the Silva119 [49] 16S rRNA database as reference sequences using confidence threshold of $70 \%$.

\section{Statistical analysis}

All of the data were analyzed by proc GLM of SAS version 9.0 software (SAS Institute Inc., Cary, NC, USA) in a $2 \times 2$ factorial arrangement with a complete randomized design by the model: $\mathrm{Y}_{\mathrm{ij}}=\mu+\mathrm{A}_{\mathrm{i}}+\mathrm{C}_{\mathrm{j}}+(\mathrm{AC})_{\mathrm{ij}}$ $+e_{i j}$, where $Y_{i j}$ is the dependent variable, $\mu$ is general mean, $A_{i}$ is fixed effect of alfalfa ( $i=0$ or 1$), C_{j}$ is the fixed effect of CSFA ( $\mathrm{j}=0$ or 1$),(A C)_{\mathrm{ij}}$ is the additive effects between alfalfa and CSFA, and $\mathrm{e}_{\mathrm{ijk}}$ is the residual effect. The normality and homogeneity of the variance were 
checked using proc UNIVARIATE. The differences in the dietary treatments were evaluated by Duncan's multiple range tests when $p<0.05$ as the criterion of significance.

OTU of all samples were rarefied to the minimum sample depth (12556 reads) based on the Mersenne Twister pseudorandom number generator of QIIME. Alpha diversity estimators Chaol and observed OTUs and rarefaction curves for the overall bacterial community and the weighted UniFrac distance matrix were calculated by using QIIME. PCoA based on weighted UniFrac distances was operated to compare all samples, and a non-parametric factorial Kruskal-Wallis sum-rank test was used to evaluate bacterial phylum and genus differences among samples.

Correlation analysis was counted of between rumen bacteria and rumen fermentation characteristics, nutrients apparent digestibility, serum biochemical parameters by spearman rank correlation test using $\mathrm{R}$ software. Significance was declared at $P<0.05$.

\section{Abbreviations}

CSFA, calcium salt of long-chain fatty acids; TVFA, total volatile fatty acids; DM, dry matter; OM, organic matter; $\mathrm{CP}$, crude protein; EE, ether extract; NDF, neutral detergent fiber; $\mathrm{ADF}$, acid detergent fiber; $\mathrm{NH}_{3}-\mathrm{N}$, ammonia nitrogen; VFA, volatile fatty acid; LDL-C, low density lipoprotein cholesterol; HDL-C, high density lipoprotein cholesterol; PCoA, principal co-ordinates analysis.

\section{Author contributions}

Y.H. designed the experiments and wrote the main manuscript text. W.N. prepared Tables 2 and 3. Q.Q. prepared Table 4; and C.X. and T.S. and H.W. revised the manuscript and analysed the results. Q.L., Z.Y. and Z.G. conducted the experiments. M.A. revised the manuscript. H.S. and B.C. are the corresponding authors and designed the experiments.

\section{CONFLICTS OF INTEREST}

The authors declare no competing financial interests.

\section{FUNDING}

This study was supported by the National Modern Agricultural Technology System (CARS-37) in China, and the Herbivore Livestock Fattening and Technique of High Quality Meat Produce Research of South China (201303144).

\section{REFERENCES}

1. Gomez-Cortes P, Frutos P, Mantecon AR, Juarez M, de la Fuente MA, Hervas G. Milk Production, Conjugated Linoleic Acid Content, and in Vitro Ruminal Fermentation in Response to High Levels of Soybean Oil in Dairy Ewe Diet. J Dairy Sci. 2008; 4:1560-69. http://doi.org/10.3168/ jds.2007-0722.

2. Gillis MH, Duckett SK, Sackmann JR. Effects of Supplemental Rumen-Protected Conjugated Linoleic Acid Or Corn Oil On Lipid Content and Palatability in Beef Cattle. J Anim Sci. 2007; 6:1504. http://doi.org/10.2527/ jas.2006-581.

3. Do Prado RM, Palin MF, Do Prado IN, Dos Santos GT, Benchaar C, Petit HV. Milk Yield, Milk Composition, and Hepatic Lipid Metabolism in Transition Dairy Cows Fed Flaxseed Or Linola. J Dairy Sci. 2016; 11:8831-46. http:// doi.org/10.3168/jds.2016-11003.

4. Bock BJ, Harmon DL Jr, Brandt RT, Schneider JE. Fat Source and Calcium Level Effects On Finishing Steer Performance, Digestion, and Metabolism. J Anim Sci. 1991; 5:2111-224.

5. Caldari-Torres C, Lock AL, Staples CR, Badinga L. Performance, Metabolic, and Endocrine Responses of Periparturient Holstein Cows Fed 3 Sources of Fat1. J Dairy Sci. 2011; 3:1500-10. http://doi.org/10.3168/jds.2010-3748.

6. Salehi R, Colazo MG, Oba M, Ambrose DJ. Effects of Prepartum Diets Supplemented with Rolled Oilseeds On Calf Birth Weight, Postpartum Health, Feed Intake, Milk Yield, and Reproductive Performance of Dairy Cows. J Dairy Sci. 2016; 5:3584-97. http://doi.org/10.3168/ jds.2015-10186.

7. Ripoll G, Alberti P, Joy M. Influence of Alfalfa GrazingBased Feeding Systems On Carcass Fat Colour and Meat Quality of Light Lambs. Meat Sci. 2012; 2:457-64. http:// doi.org/10.1016/j.meatsci.2011.09.007.

8. Ripoll G, Gonzalez-Calvo L, Molino F, Calvo JH, Joy M. Effects of Finishing Period Length with Vitamin E Supplementation and Alfalfa Grazing On Carcass Color and the Evolution of Meat Color and the Lipid Oxidation of Light Lambs. Meat Sci. 2013; 4:906-13. http://doi. org/10.1016/j.meatsci.2012.09.017.

9. Capra G, Martinez R, Fradiletti F, Cozzano S, Repiso L, Marquez R, Ibanez F. Meat Quality of Rabbits Reared with Two Different Feeding Strategies: With Or without Fresh Alfalfa Ad Libitum. World Rabbit Sci. 2013; 1:23-32. http://doi.org/10.4995/wrs.2013.1197.

10. Shi YH, Wang J, Guo R, Wang CZ, Yan XB, Xu B, Zhang DQ. Effects of Alfalfa Saponin Extract On Growth Performance and some Antioxidant Indices of Weaned Piglets. Livest Sci. 2014; 257-62. http://doi.org/10.1016/j. livsci.2014.05.032.

11. Mattioli S, Dal Bosco A, Martino M, Ruggeri S, Marconi O, Sileoni V, Falcinelli B, Castellini C, Benincasa P. Alfalfa and Flax Sprouts Supplementation Enriches the Content of Bioactive Compounds and Lowers the Cholesterol in Hen Egg. J Funct Foods. 2016; 454-62. http://doi.org/10.1016/j. jff.2016.02.007.

12. Alhidary IA, Abdelrahman MM, Alyemni AH, Khan RU, Al-Saiady MY, Amran RA, Alshamiry FA. Effect of Alfalfa 
Hay On Growth Performance, Carcass Characteristics, and Meat Quality of Growing Lambs with Ad Libitum Access to Total Mixed Rations. Rev Bras Zootecn. 2016; 6:302-08. http://doi.org/10.1590/S1806-92902016000600004.

13. Ouyang K, Xu M, Jiang Y, Wang W. Effects of Alfalfa Flavonoids On Broiler Performance, Meat Quality, and Gene Expression. Can J Anim Sci. 2016; 3:332-41. http:// doi.org/10.1139/cjas-2015-0132.

14. Liu J, Zhang M, Zhang R, Zhu W, Mao S. Comparative Studies of the Composition of Bacterial Microbiota Associated with the Ruminal Content, Ruminal Epithelium and in the Faeces of Lactating Dairy Cows. Microb Biotechnol. 2016; 2:257-68. http://doi. org/10.1111/1751-7915.12345.

15. Baumler AJ, Sperandio V. Interactions Between the Microbiota and Pathogenic Bacteria in the Gut. Nature. 2016; 7610:85-93. http://doi.org/10.1038/nature18849.

16. Pordomingo AJ, Grigioni G, Carduza F, Volpi Lagreca G. Effect of Feeding Treatment During the Backgrounding Phase of Beef Production From Pasture On: I. Animal Performance, Carcass and Meat Quality. Meat Sci. 2012; 4:939-46. http://doi.org/10.1016/j.meatsci.2011.11.036.

17. Maia MRG, Fonseca AJM, Oliveira HM, Mendonca C, Cabrita ARJ. The Potential Role of Seaweeds in the Natural Manipulation of Rumen Fermentation and Methane Production. Sci Rep-Uk. 2016; 32321:32321. http://doi. org/10.1038/srep32321.

18. Hristov AN, Ropp JK, Hunt CW. Effect of Barley and its Amylopectin Content On Ruminal Fermentation and Bacterial Utilization of ammonia-N in Vitro. Anim Feed Sci Tech. 2002; PII S0377-8401(02)00076-71-4: 25-36. http:// doi.org/10.1016/S0377-8401(02)00076-7.

19. Barletta RV, Gandra JR, Bettero VP, Araujo CE, Del Valle TA, de Almeida GF, de Jesus EF, Mingoti RD, Benevento BC, de Freitas Junior JE, Renno FP. Ruminal Biohydrogenation and Abomasal Flow of Fatty Acids in Lactating Cows: Oilseed Provides Ruminal Protection for Fatty Acids. Anim Feed Sci Tech. 2016; 111-21. http://doi. org/10.1016/j.anifeedsci.2016.06.011.

20. Broudiscou L, Pochet S, Poncet C. Effect of Linseed Oil Supplementation On Feed Degradation and Microbial Synthesis in the Rumen of Ciliate-Free and Refaunated Sheep. Anim Feed Sci Tech. 1994; 3-4: 189-202. http://doi.org/10.1016/0377-8401(94)90045-0.

21. Kim YK, Schingoethe DJ, Casper DP, Ludens FC. Supplemental Dietary-Fat From Extruded Soybeans and Calcium Soaps of Fatty-Acids for Lactating Dairy-Cows. J Dairy Sci. 1993; 1:197-204. http://doi.org/10.3168/jds. S0022-0302(93)77338-5.

22. VanNevel CJ, Demeyer DI. Effect of $\mathrm{pH}$ On Biohydrogenation of Polyunsaturated Fatty Acids and their Ca-salts by Rumen Microorganisms in Vitro. archives of animal nutrition-archiv fur tierernahrung. 1996; 2:151-57.
23. Bradford BJ, Harvatine KJ, Allen MS. Dietary Unsaturated Fatty Acids Increase Plasma Glucagon-Like Peptide-1 and Cholecystokinin and May Decrease Premeal Ghrelin in Lactating Dairy Cows. J Dairy Sci. 2008; 4:1443-50. http:// doi.org/10.3168/jds.2007-0670.

24. Bettero VP, Del Valle TA, Barletta RV, de Araújo CE, Ferreira De Jesus E, de Almeida GF, Takiya CS, Zanferari F, de Paiva PG, de Freitas Júnior JE, Rennó FP. Use of Protected Fat Sources to Reduce Fatty Acid Biohydrogenation and Improve Abomasal Flow in Dry Dairy Cows. Anim Feed Sci Tech. 2017; 30-38. http://doi. org/10.1016/j.anifeedsci.2016.12.007.

25. Garcia Bojalil CM, Staples CR, Risco CA, Savio JD, Thatcher WW. Protein Degradability and Calcium Salts of Long-Chain Fatty Acids in the Diets of Lactating Dairy Cows: Productive Responses. J Dairy Sci. 1998; 5:1374-84.

26. Zened A, Combes S, Cauquil L, Mariette J, Klopp C, Bouchez O, Troegeler-Meynadier A, Enjalbert F. Microbial Ecology of the Rumen Evaluated by 454 GS FLX Pyrosequencing is Affected by Starch and Oil Supplementation of Diets. Fems Microbiol Ecol. 2013; 2:504-14. http://doi.org/10.1111/1574-6941.12011.

27. Kau AL, Ahern PP, Griffin NW, Goodman AL, Gordon JI. Human Nutrition, the Gut Microbiome and the Immune System. Nature. 2011; 7351:327-36. http://doi.org/10.1038/ nature 10213.

28. Eisler MC, Lee MRF, Tarlton JF, Martin GB, Beddington J, Dungait JAJ, Greathead H, Liu J, Mathew S, Miller H, Misselbrook T, Murray P, Vinod VK, et al. Steps to Sustainable Livestock. Nature. 2014; 7490:32-34.

29. Jami E, Mizrahi I. Composition and Similarity of Bovine Rumen Microbiota across Individual Animals. Plos One. 2012; e:333063. http://doi.org/10.1371/journal. pone.0033306.

30. Paz HA, Anderson CL, Muller MJ, Kononoff PJ, Fernando SC. Rumen Bacterial Community Composition in Holstein and Jersey Cows is Different under Same Dietary Condition and is Not Affected by Sampling Method. Front Microbiol. 2016; http://doi.org/10.3389/fmicb.2016.01206.

31. Zhang R, Zhu W, Zhu W, Liu J, Mao S. Effect of Dietary Forage Sources On Rumen Microbiota, Rumen Fermentation and Biogenic Amines in Dairy Cows. J Sci Food Agr. 2014; 9:1886-95. http://doi.org/10.1002/ jsfa.6508.

32. Maczulak AE, Dehority BA, Palmquist DL. Effects of Long-Chain Fatty-Acids On Growth of Rumen Bacteria. Appl Environ Microb. 1981; 5:856-62.

33. Wang W, Li C, Li F, Wang X, Zhang X, Liu T, Nian F, Yue X, Li F, Pan X, La Y, Mo F, Wang F, et al. Effects of Early Feeding On the Host Rumen Transcriptome and Bacterial Diversity in Lambs. Sci Rep-Uk. 2016; 32479:32479. http:// doi.org/10.1038/srep32479.

34. Kong Y, Teather R, Forster R. Composition, Spatial Distribution, and Diversity of the Bacterial Communities 
in the Rumen of Cows Fed Different Forages. Fems Microbiol Ecol. 2010; 3:612-22. http://doi. org/10.1111/j.1574-6941.2010.00977.x.

35. Stevenson DM, Weimer PJ. Dominance of Prevotella and Low Abundance of Classical Ruminal Bacterial Species in the Bovine Rumen Revealed by Relative Quantification Real-Time PCR. Appl Microbiol Biot. 2007; 1:165-74. http://doi.org/10.1007/s00253-006-0802-y.

36. Palmonari A, Stevenson DM, Mertens DR, Cruywagen CW, Weimer PJ. PH Dynamics and Bacterial Community Composition in the Rumen of Lactating Dairy Cows. J Dairy Sci. 2010; 1:279-87. http://doi.org/10.3168/ jds.2009-2207.

37. Thoetkiattikul $\mathrm{H}$, Mhuantong $\mathrm{W}$, Laothanachareon $\mathrm{T}$, Tangphatsornruang S, Pattarajinda V, Eurwilaichitr L, Champreda V. Comparative Analysis of Microbial Profiles in Cow Rumen Fed with Different Dietary Fiber by Tagged 16S rRNA Gene Pyrosequencing. Curr Microbiol. 2013; 2:130-37. http://doi.org/10.1007/s00284-013-0336-3.

38. Myer PR, Smith TPL, Wells JE, Kuehn LA, Freetly HC. Rumen Microbiome From Steers Differing in Feed Efficiency. Plos One. 2015; 6:http://doi.org/10.1371/journal. pone.0129174.

39. Clemente JC, Ursell LK, Parfrey LW, Knight R. The Impact of the Gut Microbiota on Human Health: An Integrative View. Cell. 2012; 6:1258-70. http://doi.org/10.1016/j. cell.2012.01.035.

40. Pedersen HK, Gudmundsdottir V, Nielsen HB, Hyotylainen T, Nielsen T, Jensen BAH, Forslund K, Hildebrand F, Prifti E, Falony G, Le Chatelier E, Levenez F, Dore J, et al. Human Gut Microbes Impact Host Serum Metabolome and Insulin Sensitivity. Nature. 2016; 7612:376. http://doi. org/10.1038/nature18646.

41. Tang YQ, Shigematsu T, Morimura S, Kida K. Microbial Community Analysis of Mesophilic Anaerobic Protein
Degradation Process Using Bovine Serum Albumin (BSA)fed Continuous Cultivation. J Biosci Bioeng. 2005; 2:150-64. http://doi.org/10.1263/jbb.99.150.

42. Association of Official Analytical Chemists. Official methods of analysis. Association of Official Analytical Chemists, Arlington, VA, USA. Association of Official Analytical Chemists. 1990; 1-684.

43. Van Keulen J, Young BA. Evaluation of Acid Insoluble Ash as a Natural Marker in Ruminant Digestibility Studies. J Anim Sci. 1977; 2:282-87.

44. He Y, Niu W, Xia C, Cao B. Daidzein Reduces the Proliferation and Adiposeness of 3T3-L1 Preadipocytes Via Regulating Adipogenic Gene Expression. J Funct Foods. 2016; 446-53. http://doi.org/10.1016/j.jff.2016.01.044.

45. Broderick GA, Kang JH. Automated Simultaneous Determination of Ammonia and Total Amino-Acids in Ruminal Fluid and Invitro Media. J Dairy Sci. 1980; 1:64-75.

46. Edgar RC. UPARSE: Highly Accurate OTU Sequences From Microbial Amplicon Reads. Nat Methods. 2013; 10:996. http://doi.org/10.1038/NMETH.2604.

47. Schloss PD, Gevers D, Westcott SL. Reducing the Effects of PCR Amplification and Sequencing Artifacts on 16S rRNA-Based Studies. Plos One. 2011; e2731012: http://doi. org/10.1371/journal.pone.0027310.

48. Wang Q, Garrity GM, Tiedje JM, Cole JR. Naive Bayesian Classifier for Rapid Assignment of rRNA Sequences Into the New Bacterial Taxonomy. Appl Environ Microb. 2007; 16:5261-67. http://doi.org/10.1128/AEM.00062-07.

49. Quast C, Pruesse E, Yilmaz P, Gerken J, Schweer T, Yarza P, Peplies J, Gloeckner FO. The SILVA Ribosomal RNA Gene Database Project: Improved Data Processing and Web-Based Tools. Nucleic Acids Res. 2013; D1:D590-96. http://doi.org/10.1093/nar/gks1219. 